\title{
Energy Metabolism in Human Erythrocytes
}

\author{
II. EFFECTS OF GLUCOSE DEPLETION \\ Stephen A. Feig, George B. Segel, Stephen B. Shohet, and \\ David G. Nathan \\ From the Division of Hematology of the Department of Medicine, \\ Children's Hospital Medical Center and the Department of Pediatrics, \\ Harvard Medical School, Boston, Massachusetts 02115
}

\begin{abstract}
A B S T R A C T Normal red cells were incubated in the absence of glucose to develop a system in which total adenosine triphosphate (ATP) turnover could be assessed. After $1 \mathrm{hr}$, the triose pool had been completely consumed. Thereafter, the metabolism of 2,3-diphosphoglycerate (DPG) to pyruvate and lactate was the sole significant source of ATP synthesis.
\end{abstract}

$10^{-3} \mathrm{M} \mathrm{CuCl}_{2}$, which did not enter the cells, diminished ATP utilization by more than $50 \%$. This could be only partially attributed to the inhibition by copper of residual acylation and cation pumping, which were already reduced by glucose depletion. Other membrane enzymes, which presumably function in the maintenance of membrane integrity, must, therefore, use a significant portion of erythrocyte ATP.

The behavior of glucose-depleted red cells with respect to cation transport was complex. The addition of ouabain did not decrease ATP utilization in these red cells. Ouabain inhibitable potassium influx was nearly normal after triose depletion, but total potassium influx was decreased. In contrast, the ouabain inhibitable sodium efflux was markedly reduced after triose depletion, although the concentration of ATP was $70 \%$ of normal. The dissociation of monovalent cation pumping suggests that the energy for active sodium transport is derived from a specific source (such as the ATP produced by the phosphoglycerate kinase reaction) distinct from that for potassium transport.

This work was presented in part at the Annual Meeting of the American Society of Hematology, 7 December 1970, San Juan, Puerto Rico.

Dr. Feig is the recipient of National Heart and Lung Institute Special Fellowship 5-FO3-HE-48, 588. Dr. Shohet is a Fellow of the Medical Foundation, Inc. Dr. Nathan is the recipient of U. S. Public Health Service Research Career Development Award K3-AM-35361.

Received for publication 5 November 1971 and in revised form 28 January 1972.

\section{INTRODUCTION}

The estimation of red blood cell energy utilization is complicated by the presence of the 2,3-diphosphoglycerate $(\mathrm{DFG})^{1}$ cycle. To the extent that glycolysis proceeds along this pathway no net synthesis of adenosine triphosphate (ATP) occurs. Methods are not available to measure the fraction of glycolysis that bypasses the phosphoglycerate kinase (PGK) reaction via the DPG cycle. Specific inhibitors of the enzymes of this cycle are, likewise, unavailable. Incubation of erythrocytes with fluoride, which inhibits enolase (1) and therefore arrests red cell ATP synthesis, has been used to assess ATP consumption but the consequent disruption of glycolysis by fluoride increases the ratio of reduced form of diphosphopyridine nucleotide $(\mathrm{NADH})$ to diphosphopyridine nucleotide (NAD) which, in turn, limits the activity of glyceraldehyde phosphate dehydrogenase (GPD) and results in rapid utilization of ATP stores by hexokinase and phosphofructokinase $(2,3)$.

The glucose-free red cell provides a model more amenable to the analysis of ATP utilization. The energy requiring reactions of these cells depends solely upon the initial stores of ATP and the ATP newly synthesized by the catabolism of 2,3-DPG through pyruvate kinase. This was the approach used by Whittam to study the relationship of energy metabolism to the potassium $\left(\mathrm{K}^{+}\right)$ pump (4).

In this paper, we present studies of ATP utilization in glucose-free erythrocytes. The data indicate that the red cell membrane utilizes most of the ATP available to these cells. The metabolic alterations produced by glucose depletion result in decreased total $\mathrm{K}^{+}$influx while

\footnotetext{
${ }^{1}$ Abbreviations used in this paper: FDP, fructose diphosphate; GPD, glyceraldehyde phosphate dehydrogenase; G3P, glyceraldehyde-3-phosphate; KHB, Krebs-Henseleit buffer; PGK, phosphoglycerate kinase; 2,3-DPG, 2,3-diphosphoglycerate ; $3 \mathrm{PG}, 3$-phosphoglycerate.
} 
active (ouabain-inhibitable) $\mathrm{K}^{+}$influx is only slightly decreased.

In contrast, active sodium $\left(\mathrm{Na}^{+}\right)$efflux is markedly reduced by glucose depletion which suggests that the energy for the two pumps is derived from different sources.

\section{METHODS}

Normal blood samples were anticoagulated with preservative-free heparin $(0.1 \mathrm{mg} / \mathrm{ml})$. The plasma and buffy coat were removed and the red cells were washed three times at $4^{\circ} \mathrm{C}$ with Krebs-Henseleit buffer (KHB) $(\mathrm{pH} 7.5 \pm 0.1)$ with added bovine serum albumin $(1 \mathrm{~g} / 100 \mathrm{ml})$. Glucose-replete cells were prepared by supplementing this buffer with 200 $\mathrm{mg}$ glucose $/ 100 \mathrm{ml}$. The cells were resuspended in the appropriate KHB (with or without glucose) to an approximate hematocrit of $40 \%$. Cell counts were performed in a Coulter model S counter (Coulter Electronics, Inc., Hialeah, Fla.) or by standard methods (5).

Cell suspensions $(3-8 \mathrm{ml}$ in $25 \mathrm{ml}$ Ehrlenmeyer flasks) were incubated in a $37^{\circ} \mathrm{C}$ shaking water bath at 60 oscillations $/ \mathrm{min}$. The flasks were gassed under air and $5 \% \mathrm{CO}_{2}$ to maintain $\mathrm{pH}$ at $7.5 \pm 0.1$. Additives were prepared to provide final concentrations by the addition of $10 \mu \mathrm{l}$. Filtrates were prepared at the beginning of the incubations and at desired intervals in $2 \mathrm{vol}$ of ice-cold $1 \mathrm{~N}$ perchloric acid. The supernatant filtrate was separated by two centrifugations and neutralized with $5 \mathrm{M} \mathrm{K}_{2} \mathrm{CO}_{3}$. Neutralized filtrates were frozen within $2 \mathrm{hr}$ of preparation, during which time, they were maintained at $4^{\circ} \mathrm{C}$. Filtrates were subsequently analyzed for ATP (6), adenosine diphosphate (ADP) (7), lactate (8), glucose (9), 2,3-DPG (10), glyceraldehyde-3phosphate (G3P) (11), dihydroxyacetone phosphate (DHAP) (11), fructose diphosphate (FDP) (11), and 3-phosphoglycerate (3PG) (11). Pyruvate cannot be recovered adequately from red cells (12). Therefore, cell suspensions were rapidly centrifuged at $4^{\circ} \mathrm{C}$ and filtrates prepared from the buffer, as described above. These were later analyzed for pyruvate (11). Concentrations of lactate, 2,3DPG, FDP, G3P, DHAP, 3PG, ADP, and ATP were calculated on the basis of the hematocrit at the start of the incubation. Pyruvate production was calculated by assuming that pyruvate was uniformly distributed through the buffer and cell water (assumed to occupy $70 \%$ of the packed cell volume).

Active cation fluxes were measured with ${ }^{24} \mathrm{Na}^{+}$and ${ }^{42} \mathrm{~K}^{+2}$ $(13,14)$. For $\mathrm{Na}^{+}$efflux, washed cells were incubated at $37^{\circ} \mathrm{C}$ for $3 \mathrm{hr}$ in $4 \mathrm{vol}$ of a modified $\mathrm{KHB}(\mathrm{pH} \mathrm{7.5)}$ containing glucose $(200 \mathrm{mEq} / 100 \mathrm{ml}) . \mathrm{Na}^{+}$(50 mEq/liter), $\mathrm{K}^{+}(90 \mathrm{mEq} /$ liter $)$, albumin $(1 \mathrm{~g} / 100 \mathrm{ml})$ and $1 \mathrm{mCi}^{24} \mathrm{Na}^{+}$ $\left(\mathrm{SA}=69 \mathrm{mCi} / \mathrm{mEq} \mathrm{Na}{ }^{+}\right)$. The labeled cells were then washed three times, and resuspended at $30 \%$ hematocrit in standard KHB with albumin (with or without glucose) for the incubation. Samples were obtained every $\frac{1}{2} \mathrm{hr}$ for determination of hematocrit and for measurements of radioactivity, sodium, and potassium in the supernatant buffer. Red cell electrolytes and radioactivity were measured in cells washed three times in isosmotic $\mathbf{M g C l}_{2}$. Radioactive counting was performed in a Packard "Tri-Carb" gamma scintillation spectrometer (Packard Instrument Co., Inc., Downers Grove, Ill., model 3002 ). $\mathrm{Na}^{+}$and $\mathrm{K}^{+}$concentrations were

${ }^{2} \mathrm{As}{ }^{24} \mathrm{NaCl}$ and ${ }^{2} \mathrm{KCl}$, respectively, Cambridge Nuclear Corp., Iso/Serve Div., Cambridge, Mass. measured with an internally standardized flame photometer (Instrumentation Laboratory, Inc., Lexington, Mass., model 143).

For $\mathrm{K}^{+}$influx, a $\mathrm{KHB}$ with albumin (with or without glucose) was prepared with $2 \mathrm{mEq} \mathrm{K} /$ liter. ${ }^{2} \mathrm{~K}^{+}(\mathrm{SA}=65$ $\mathrm{mCi} / \mathrm{mEq} \mathrm{K} \mathrm{K}^{+}$) was added to raise the concentration of $\mathrm{K}^{+}$ in the buffer to between 5 and $6 \mathrm{mEq} /$ liter. Washed cells were suspended in the ${ }^{12} \mathrm{~K}^{+}$-enriched buffer to an hematocrit of $30 \%$ for the incubation. Specimens were obtained in the same manner as for the ${ }^{24} \mathrm{Na}^{+}$fluxes. The fluxes were calculated for each time interval as follows:

$\mathrm{K}^{+}$influx (mEq/liter cells)

$$
=\frac{\Delta \mathrm{cpm} / \text { liter cells }}{\text { mean plasma SA }(\mathrm{cpm} / \mathrm{mEq})}
$$

$\mathrm{Na}^{+}$efflux (mEq/liter cells)

$$
=\frac{\Delta \mathrm{cpm}, \text { plasma }}{\text { mean SA cells }} \times \frac{\text { plasmatocrit }}{\text { hematocrit }}
$$

The data were then subjected to line analysis (15) to assess the significance of observed changes.

\section{RESULTS}

As noted previously by Whittam (4), three preparatory washes of red cells with $\mathrm{KHB}$ completely removed all glucose from the cells. No loss of ATP or 2,3-DPG was observed.

Metabolism. During subsequent incubations at $37^{\circ} \mathrm{C}$ of glucose-depleted cells, the concentration of ATP fell gradually over the first $3 \mathrm{hr}$ and stabilized at less than $50 \%$ of the initial value (Fig. 1). Although $10^{-4} \mathrm{M}$ ouabain did not significantly affect the rate at which ATP declined, exposure to $10^{-3} \quad \mathrm{M}^{\mathrm{CuCl}} \mathbf{2}$ markedly diminished the rate of fall of ATP. Indeed after $4 \mathrm{hr}$, the concentration of ATP in glucose-depleted cells exposed to $10^{-3} \mathrm{M}$ copper was only reduced to $85 \%$ of the initial concentration. The concentration of ADP in glucose-depleted cells was $170 \pm 60$ moles/liter cells at the start of the incubation and did not vary significantly during the studies.

Lactate production was, in all experiments, greatest in the 1 st hr (Table I). Ouabain decreased lactate production $20 \%$ during the 1 st $\mathrm{hr}$, but had no such effect subsequently. Lactate production was significantly reduced at all times by exposure to $10^{-3} \mathrm{M} \mathrm{CuCl}_{2}$. The utilization of 2,3-DPG was negligible in the 1 st $\mathrm{hr}$ of incubation, in all cases, but increased thereafter. Ouabain did not affect the utilization of 2,3-DPG but copper reduced the catabolism of 2,3-DPG by approximately $50 \%$.

Total triose phosphates (including G3P, DHAP, and the triose equivalent of FDP) were elevated at the start of the incubation, probably due to preparatory manipulations of the cells in cold buffer (Table II). Whereas the glucose-replete cells showed an accumulation of total triose phosphates during the 1st hr (3), the glucose-depleted cells metabolized their trioses com- 


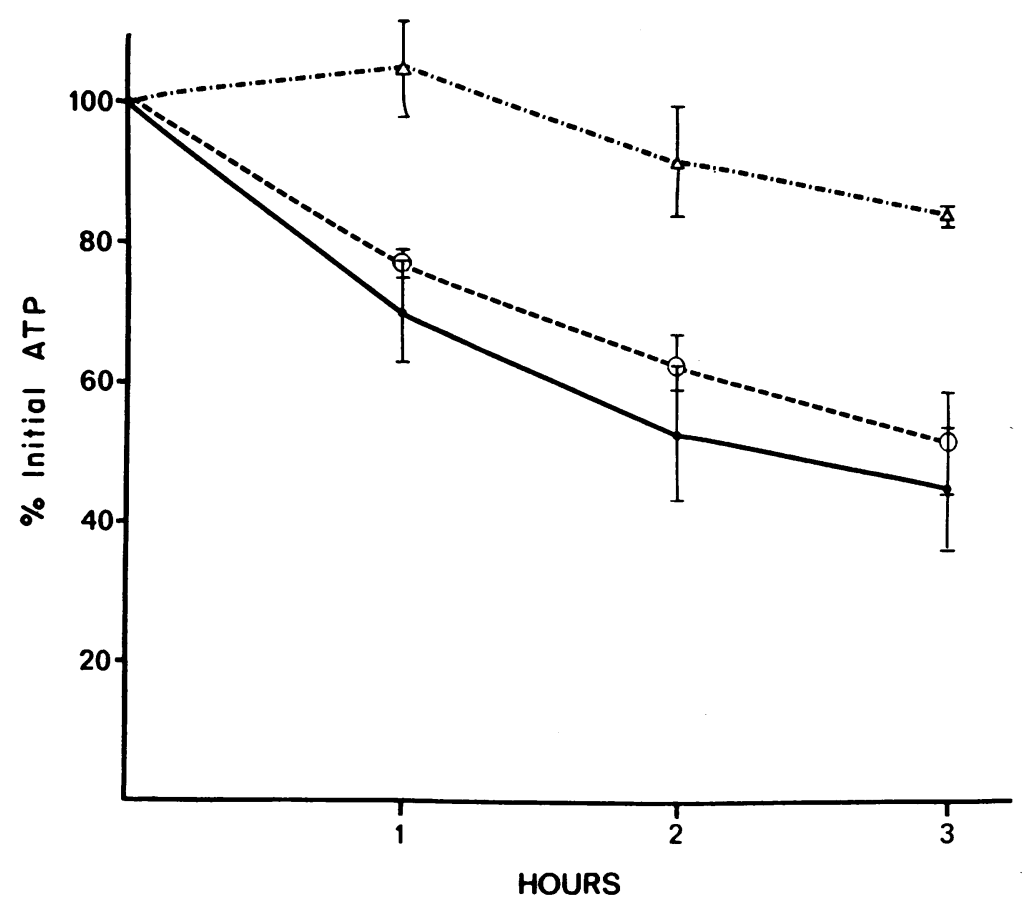

FIGURE 1 ATP concentration in glucose-depleted erythrocytes. The initial ATP was $1.43 \pm 0.24$ mmole/liter cells. ATP is stable in glucose-replete cells. $\bullet$, no additive; $O, 10^{-4} \mathrm{M}$ ouabain; $\triangle, 10^{-3} \mathrm{M} \mathrm{CuCl}_{2}$.

pletely. This accounted for most of the excess of lactate production compared with 2,3-DPG utilization in these cells during the $1 \mathrm{st} \mathrm{hr}$. 3PG decreased slightly during the incubation of glucose-depleted cells, but remained stable in the presence of glucose (.Table II).

After the $1 \mathrm{st} \mathrm{hr}$ of incubation, the utilization of 2,3DPG by glucose-depleted cells always exceeded lactate production (Table I). This was accounted for by the accumulation of pyruvate, as previously noted by Whittam (4) and Omachi, Scott, and Parry (16). In fact, the sum of pyruvate and lactate production equaled 2,3-DPG depletion (Table III). This relationship was unaffected by $10^{-3} \mathrm{M} \mathrm{CuCl}_{2}$ even though 2,3-DPG utilization was reduced $50 \%$ in the presence of copper.

Thus 2,3-DPG catabolism was the sole source of ATP production in glucose-depleted cells after the 1st $\mathrm{hr}$ of incubation. Since all the 2,3-DPG utilized was accounted for by pyruvate and lactate production (Table III) 1 mole of ATP must have been synthesized for every mole of 2,3-DPG consumed. Therefore, the sum of the decreases in concentration of 2,3DPG and ATP was taken as the net ATP utilization. Glucose-depleted red cells used nearly 1 mmole ATP/ liter cells per $\mathrm{hr}$ (Table IV). $\mathrm{CuCl}_{2}$, an inhibitor of

TABLE I

Lactate Production and 2,3-DPG Utilization in Normal Glucose-Depleted Erythrocytes

\begin{tabular}{|c|c|c|c|c|c|c|}
\hline \multirow[b]{2}{*}{ Incubation } & \multicolumn{3}{|c|}{ Lactate production } & \multicolumn{3}{|c|}{ 2,3-DPG utilization } \\
\hline & No additive & $10^{-4} \mathrm{M}$ ouabain & $10^{-3} \mathrm{M} \mathrm{CuCl}_{2}$ & No additive & $10^{-4} \mathrm{M}$ ouabain & $10^{-3} \mathrm{M} \mathrm{CuCl}_{2}$ \\
\hline$h r$ & \multicolumn{6}{|c|}{ mmoles/liter cells per $h r$} \\
\hline 1st & $0.95 \pm 0.18^{*}$ & $0.74 \pm 0.22 \S$ & $0.74 \pm 0.07 \S$ & $0.19 \pm 0.32^{*}$ & $0.00 \pm 0.36 \S$ & $0.08 \pm 0.49 \S$ \\
\hline 2nd & $0.33 \pm 0.09^{*}$ & $0.33 \pm 0.03 \S$ & $0.24 \pm 0.10 \S$ & $0.71 \pm 0.24^{*}$ & $0.75 \pm 0.28 \S$ & $0.45 \pm 0.23 \S$ \\
\hline $3 \mathrm{rd}$ & $0.28 \pm 0.03 \ddagger$ & $0.21 \pm 0.09 \S$ & $0.11 \pm 0.01 \S$ & $0.78 \pm 0.11 \ddagger$ & $0.60 \pm 0.20 \S$ & $0.29 \pm 0.02 \S$ \\
\hline
\end{tabular}

Incubations were performed at $37^{\circ} \mathrm{C}$. Red cells were suspended in $\mathrm{KHB}$ without glucose.

Values are expressed as the mean \pm SD unless otherwise noted.

$* \mathrm{~N}=8$.

$\ddagger \mathrm{n}=6$.

$\$$ Value is the mean and range of two determinations. 
TABLE II

The Effect of Glucose Depletion on Total Triose Phosphates* and 3-Phosphoglycerate in Normal Red Cells

\begin{tabular}{rccccc}
\hline & \multicolumn{2}{c}{ Total triose phosphates* } & & \multicolumn{2}{c}{ 3-Phosphoglycerate } \\
\cline { 5 - 6 } Time & $10 \mathrm{~mm}$ glucose & No glucose & & 10 mM glucose & No glucose \\
\hline $\min$ & 500 & 590 & & 81 & 68 \\
0 & 1050 & 0 & & 78 & 40 \\
60 & - & - & & 95 & 33 \\
120 & & & & \\
\hline
\end{tabular}

Cells were incubated at $37^{\circ} \mathrm{C}$.

* Total triose phosphates $=2\{\mathrm{FDP}\}+\{\mathrm{G} 3 \mathrm{P}\}+\{\mathrm{DHAP}\}$.

ATPase (17), acylase (18), and probably other membrane enzymes, markedly decreased ATP use. Surprisingly, $10^{-4} \mathrm{M}$ ouabain did not reduce ATP utilization. This observation prompted a close observation of cation transport in glucose-depleted cells.

Cation transport. Measurement of ouabain inhibitable (active) $\mathrm{K}^{+}$influx (Fig. $2 a$ and Table V) revealed only slight depression after the $1 \mathrm{st} \mathrm{hr}$ in glucose-free red cells. The cells exhibited a small net loss of $\mathrm{K}^{+}(0.7 \mathrm{mEq} /$ liter cells per $\mathrm{hr})$ due to a decline in the $\mathrm{K}^{+}$influx that was not inhibitable by ouabain. When red cells were preincubated in the modified KHB for $\mathrm{Na}^{+}$labeling (but without ${ }^{24} \mathrm{Na}^{+}$), the ${ }^{{ }^{2}} \mathrm{~K}^{+}$influx remained $1.3 \mathrm{mEq} /$ liter cells per $\mathrm{hr}$.

In contrast to the barely detectable decrease in active $\mathrm{K}^{+}$transport, the ouabain-inhibitable $\mathrm{Na}^{+}$efflux in the glucose-depleted cells decreased abruptly by nearly two-thirds after $1 \mathrm{hr}$ (Fig. $2 b$ and Table V). This marked reduction of the ouabain inhibitable $\mathrm{Na}^{+}$efflux was highly significant $(P<0.005)$ and was substantiated in two additional experiments. The intracellular sodium concentration $\left[\mathrm{Na}_{1}{ }^{+}\right]$remained stable initially, then increased. Despite the gain of red cell $\mathrm{Na}^{+}$, the glucose-depleted cells failed to increase active $\mathrm{Na}^{+}$ (19). As a result, the ratio of active $\mathrm{Na}^{+}$efflux to

TABLE III

Products of 2,3-DPG Catabolism in GlucoseDepleted Erythrocytes

\begin{tabular}{lcccc}
\hline & $\begin{array}{c}\text { Lactate } \\
\text { production }\end{array}$ & $\begin{array}{c}\text { Pyruvate } \\
\text { production }\end{array}$ & $\begin{array}{c}\text { Lactate plus } \\
\text { pyruvate } \\
\text { production }\end{array}$ & $\begin{array}{c}\text { 2,3-DPG } \\
\text { utilization }\end{array}$ \\
\hline & & \multicolumn{2}{c}{ mmoles/liter cells per $h r$} & \\
No additive & $0.33 \pm 0.02$ & $0.33 \pm 0.11$ & $0.66 \pm 0.08$ & $0.73 \pm 0.10$ \\
$10^{-3} \mathrm{M} \mathrm{CuCl}_{2}$ & $0.18 \pm 0.02$ & $0.17 \pm 0.03$ & $0.35 \pm 0.01$ & $0.37 \pm 0.08$ \\
\hline
\end{tabular}

Cells were incubated as described in Table $I$.

The measurements of pyruvate, lactate, and 2,3-DPG were made hourly over a $4 \mathrm{hr}$ period. The calculations of hourly production and utilization are derived from values observed from the 2 nd through the 4 th $\mathrm{hr}$. Each hourly production or utilization rate represents the mean and range of two separate experiments.
TABLE IV

ATP Utilization in Normal Glucose-Depleted Erythrocytes

\begin{tabular}{cccc}
\hline Incubation & No additive & $10^{-4} \mathrm{M}$ ouabain & $10^{-\mathrm{J}_{\mathrm{M} \mathrm{CuCl}}}$ \\
\hline$h r$ & \multicolumn{3}{c}{ mmoles/liter cells per $h r$} \\
2nd & $0.92 \pm 0.23^{*}$ & $1.22 \pm 0.22 \S$ & $0.58 \pm 0.21 \S$ \\
3rd & $0.95 \pm 0.18 \ddagger$ & $1.03 \pm 0.27 \S$ & $0.38 \pm 0.40 \S$ \\
4th & $0.76 \pm 0.11 \S$ & $0.68 \pm 0.38 \S$ & $0.38 \pm 0.40 \S$
\end{tabular}

Cells were incubated for $4 \mathrm{hr}$, as described in Table I and with the indicated additives. The hourly utilization of ATP (mmole/liter cells) was calculated from the sum of the decreases in the concentrations of ATP and 2,3-DPG. Values are expressed as the mean \pm SD.

$* \mathrm{~N}+8$

$\ddagger \mathrm{n}=6$.

$\S \mathrm{n}=4$.

the internal $\mathrm{Na}^{+}$concentration declined precipitously (Fig. 3). The hematocrits of the samples did not vary significantly during the incubations.

\section{DISCUSSION}

This method of preparation of red cells completely eliminated intracellular glucose without lowering ATP concentration. During the $1 \mathrm{st} \mathrm{hr}$ of incubation, lactate production always exceeded the utilization of 2,3-DPG.

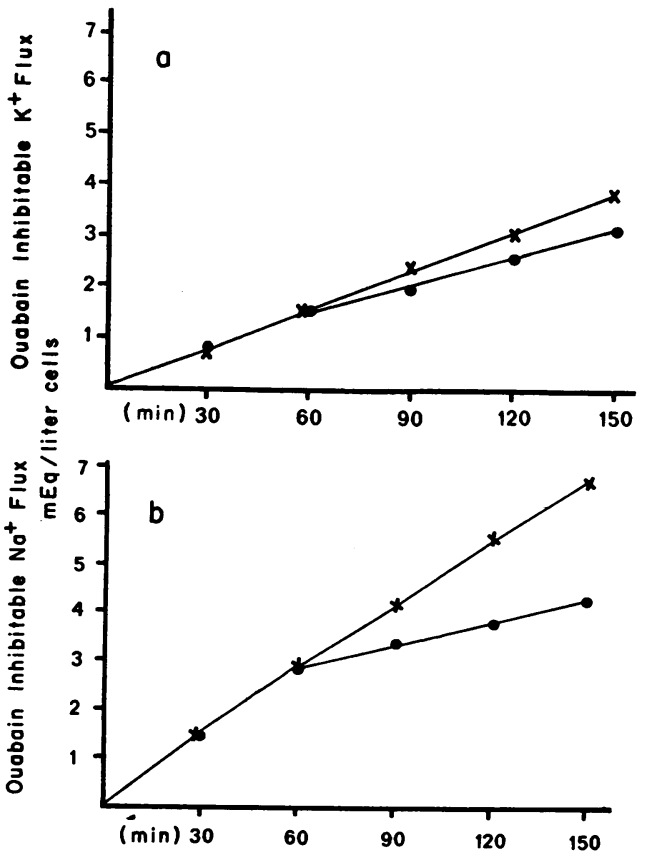

FIGURE 2 The effect of glucose depletion on ouabain inhibitable potassium $(a)$ and sodium $(b)$ flux in normal erythrocytes. Each graph shows the results of one of three experiments which produced nearly identical results. $\times 10 \mathrm{~mm}$, glucose; $\bullet$, no glucose. 
This was the result of the metabolism of glycolytic intermediates, especially the total triose pool, which had accumulated during the preparatory washes. Although the subsequent metabolism of these intermediates was accounted for as lactate produced, their route of metabolism, whether via PGK or DPG mutase, could not be determined. Therefore, their contribution to ATP synthesis could not be assessed. After $1 \mathrm{hr}$ (when the triose pool had been consumed) 2,3-DPG was quantitatively metabolized to pyruvate and lactate, confirming the data of Whittam (4). Pyruvate accumulation was undoubtedly due to a decrease in the ratio of NADH to NAD, secondary to the depletion of substrate for the GPD reaction $(4,16)$.

The metabolism of 2,3-DPG to pyruvate and lactate is the sole significant pathway for ATP synthesis in this catabolic model. Since mature red cells were studied, there was no appreciable mitochondrial ATP synthesis. Another alternate source of ATP production is the adenylate kinase ( $\mathrm{AK})$ reaction. Even with recycling, this would not have significantly increased ATP synthesis after the $1 \mathrm{st}$ hr by more than $0.1 \mathrm{mmole} /$ liter cells per $\mathrm{hr}^{3}$ The last known alternate source of ATP production is the hexose monophosphate shunt. Pentose phosphate from nucleotide catabolism could

${ }^{3}$ This was calculated as follows: Since the ADP concentration was constant, ATP could only be produced from the ADP which appeared as a result of the net use of ATP. From the 2nd through the 4th $\mathrm{hr}$, inclusive, this amounted to $0.33 \mathrm{mmoles} /$ liter cells. Two ADP are necessary to produce a single ATP via AK. Thus, even with total recycling, less than 0.3 mmoles of ATP could have been produced in the $3 \mathrm{hr}$ period by this reaction.

\section{TABLE V}

The Effect of Glucose Depletion on Cation Flux in Normal Red Cells

\begin{tabular}{|c|c|c|c|c|}
\hline & $\begin{array}{l}\text { Total } \\
\text { influx }\end{array}$ & $\begin{array}{l}\text { Ouabain } \\
\text { inhibitable } \\
\text { influx }\end{array}$ & $\begin{array}{l}\text { Total } \\
\text { efflux }\end{array}$ & Net flux \\
\hline & \multicolumn{4}{|c|}{$m E q /$ liter cells per $h r$} \\
\hline \multicolumn{5}{|l|}{ Potassium } \\
\hline Glucose replete & 2.1 & $1.4 \pm 0.1$ & 2.1 & 0 \\
\hline \multirow[t]{2}{*}{ Glucose depleted } & 1.5 & 1.1 & 2.2 & -0.7 \\
\hline & $\begin{array}{l}\text { Total } \\
\text { efflux }\end{array}$ & $\begin{array}{c}\text { Ouabain } \\
\text { inhibitable } \\
\text { efflux }\end{array}$ & $\begin{array}{l}\text { Total } \\
\text { influx }\end{array}$ & Net flux \\
\hline \multicolumn{5}{|l|}{ Sodium } \\
\hline Glucose replete & $4.0 \pm 0.1$ & $2.8 \pm 0.1$ & $4.0 \pm 0.1$ & 0 \\
\hline Glucose depleted & 2.2 & 1.0 & $2.5 \pm 0.2$ & $+0.3 \pm 0.2$ \\
\hline
\end{tabular}

Cells were incubated as described in Table $I$. The values represent the mean and range of three experiments. Where no range is shown, there was no variation observed. Flux measurements were performed every $\frac{1}{2} \mathrm{hr}$ for $2 \frac{1}{2} \mathrm{hr}$. In glucose-replete cells, hourly flux was calculated from these data. In glucose-depleted cells, average hourly flux was calculated from 1 to $2 \frac{1}{2} \mathrm{hr}$ to determine the flux rate after the depletion of trioses (see Fig. 2).

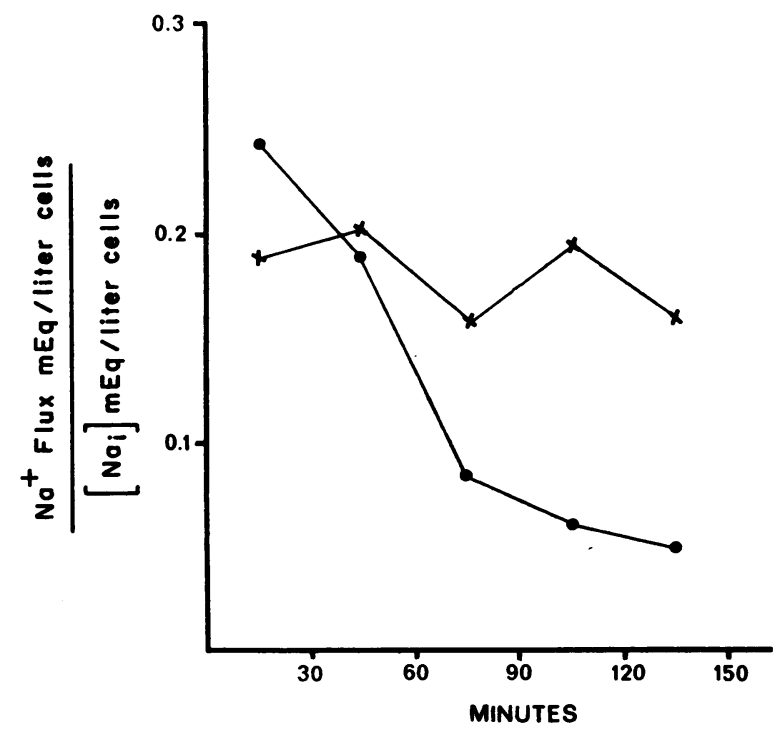

FIgURE 3 The relationship of sodium flux to internal sodium concentration; the effect of glucose depletion. $X, 10$ mM glucose; $\bullet$, no glucose.

provide a source of G3PD but significant contribution of this pathway was ruled out by the stoichiometry of 2,3-DPG conversion to pyruvate and lactate. Therefore, after the depletion of trioses, ATP turnover could be calculated as the sum of the net changes in the concentrations of ATP and 2,3-DPG. During this period of relatively stable ATP turnover, certain membrane reactions known to use ATP were evaluated in order to assess the influence of their activities on the energy economy of the red cell."

For a first approximation of the influence of membrane reactions of ATP utilization, the cells were incubated with $10^{-3} \mathrm{M} \mathrm{CuCl}$. This nonspecific inhibitor markedly reduced the rate of ATP utilization in these cells. The concentration of ATP was maintained while the stoichiometry of 2,3-DPG conversion to pyruvate and lactate remained undisturbed. The maintenance of this stoichiometry suggests that copper did not interfere with the function of pyruvate kinase. Since copper affects pyruvate kinase function at concentrations greater than $10^{-8} \mathrm{M}(21)$, it seems unlikely that a significant fraction of the copper in the incubate entered the red cells. Therefore, we postulate that the effects of copper on ATP utilization were confined to the membrane and certainly included depression of acylase and $\left(\mathrm{Na}^{+}\right.$and $\left.\mathrm{K}^{+}\right)$ATPase $(17,18)$ as well as other unspecified ATP-utilizing reactions.

"A potential spurious "use" of ATP is the conversion of $3 P G$ to 2,3-DPG. Since the concentration of 3PG (Table II) remained well below the $K_{m}$ for the "backward" PGK reaction,$\left(2.8 \times 10^{-4} \mathrm{M}\right)(20)$, it seems unlikely that this reaction was a significant source of ATP utilization. 
Acylase activity is thought to consume very little ATP in glucose-replete cells, and the rate of acylation of phospholipid is even further reduced in glucosedepleted cells (22). The contribution of acylase to ATP economy in glucose-depleted cells was therefore considered no further.

Cation transport is thought to utilize $30 \%$ of red cell ATP turnover in glucose-replete cells (23), however, the relationship of cation transport to energy metabolism in glucose-free red cells was so complex that accurate assessment of its energy requirement was not possible. Ouabain which inhibits active transport (24), usually produces a decrease in lactate production in glucose-replete red cells (25). This is mediated by a decrease in production of ADP by membrane $\left(\mathrm{Na}^{+}\right.$and $\left.\mathrm{K}^{+}\right)$ATPase. The decreased production of ADP reduces the activity of PGK (7). After the depletion of trioses in glucose-free red cells, reduced ADP production cannot alter the flow of metabolites through PGK. Thus, no decrease in lactate and pyruvate production in the presence of $10^{-4} \mathrm{M}$ ouabain was expected or observed. However, the lack of effect of ouabain on either the concentration or utilization of ATP in glucose-free cells was unexpected and prompted closer scrutiny of the cation pump in these cells. ${ }^{.}$

The effects of glucose depletion on sodium and potassium transport were markedly disparate. In contrast to Whittam's observations of a decrease in active $\mathrm{K}^{+}$influx, in parallel with red cell ATP concentration (4), we noted very little decrease in active $\mathrm{K}^{+}$pumping in glucose-free cells, even when red cell ATP concentration was reduced by over $50 \%$. The failure to confirm Whittam's findings may, in part, be due to his use of a buffer containing $10 \mathrm{~mm}$ phosphate, which we have observed to cause a $10-15 \%$ decrease in ATP concentration and a similar reduction in active $\mathrm{K}^{+}$influx. However, this factor alone would not completely reconcile the differences. The data of Glynn are more similar to those obtained in the present study (30). He subjected cells to prolonged incubation without glucose and observed a moderate rate of active $\mathrm{K}^{+}$influx at a time when the concentration of ATP must have been extremely low.

\footnotetext{
- While our data for normal potassium transport are very similar to previous reports $(26-28)$, our values for sodium transport are consistently higher than those in the literature $(26,28,29)$. Methodologic differences account for most of these discrepancies. For instance, Post and Jolly used cells that had been stored for prolonged periods at $2^{\circ} \mathrm{C}$, which would alter their internal cation concentration and metabolism (26). Tosteson (28) and Solomon (29) studied cells in plasma which presumably had a lower potassium concentration than our buffer as well as other unspecified differences which may have affected $\mathrm{Na}^{+}$transport.

${ }^{\circ}$ Feig, S. A. Unpublished data.
}

The effects of glucose depletion on the $\mathrm{Na}^{+}$pump were much more profound. Active $\mathrm{Na}^{+}$efflux was reduced nearly $70 \%$ when triose depletion was complete. The effect on $\mathrm{Na}^{+}$transport was further accentuated by the inability of glucose-depleted cells to increase $\mathrm{Na}^{+}$pumping in response to increased $\left[\mathrm{Na}_{1}{ }^{+}\right]$(19).

Clearly, the diminution of sodium transport in glucose-free red cells was not related to ATP concentration. First, the change in rate was abrupt; it occurred coincident with the disappearance of trioses. The rate did not decrease further thereafter, although the concentration of ATP continued to decline. Second, the young red cells of patients with hemoglobin inclusions pump $\mathrm{Na}^{+}$at an accelerated rate, even though their intracellular ATP concentrations are reduced to values similar to those observed in glucose-depleted cells after $1 \mathrm{hr}$ of incubation (31). ${ }^{\circ}$ It also seems unlikely that the marked effect of glucose depletion on $\mathrm{Na}^{+}$pumping was due to a higher $K_{m}$ ATP for that reaction than for the $\mathrm{K}^{+}$pump, since the change was abrupt and occurred exactly when ATP ceased to be produced by PGK.

Parker and Hoffman (32) and Zarkowsky and Nathan (7) have described experiments linking PGK to the control of glycolysis exerted by membrane $\left(\mathrm{Na}^{+}\right.$ and $\mathrm{K}^{+}$) ATPase. Schrier has suggested that the energy for cation pumping may actually be derived from membrane-bound PGK which could provide the ATP necessary for ATPase and, in turn, be stimulated by the ADP produced (33).

Our present data support this hypothesis in part. It appears that the rate of $\mathrm{Na}^{+}$pumping is indeed markedly reduced when PGK activity is lost by the depletion of triose in glucose-free cells. This suggests that the $\mathrm{Na}^{+}$pump derives its energy from the ATP produced by PGK. In contrast $\mathrm{K}^{+}$pumping seems to be independent of the control exerted by PGK, and hence the inhibition of potassium pumping by ouabain had no effect on ATP production or utilization. In fact. potassium pumping may be dependent upon a more general pool of intracellular ATP and may only cease when this pool is markedly depleted, as suggested by Glynn's data (30) and our own. These results indicate that the $\mathrm{Na}^{+}$and $\mathrm{K}^{+}$pumps of human red cells are not linked in an obligatory fashion. Such dissociation was postulated by Solomon (29) nearly 20 yr ago. On the other hand, certain well-accepted studies of the $\mathrm{Na}^{+}$and $\mathrm{K}^{+}$pumps in human red cells have led to the conclusion that the two pumps are in fact closely linked and that both derive their energy from a common pool. For example, red cell ghosts resealed around ATP, pump both sodium and potassium at rates equal to those observed in intact cells (34). Removal of potassium from the external medium abolishes both 
sodium pumping (35) and the ouabain sensitive component of erythrocyte lactate production (36). However. the above mentioned studies do not eliminate the possibility that in intact cells the two pumps, though interdependent, derive their ATP from separate sources.

Further experiments designed to investigate the relationship of $\mathrm{PGK}$ to $\mathrm{Na}^{+}$and $\mathrm{K}^{+}$pumping utilizing the red cells of patients deficient in erythrocyte PGK (37) and pyruvate kinase are now in progress. These experiments will provide more secure data concerning the pump dissociation that is suggested by the studies of glucose-free red cells.

In summary, glucose-depleted erythrocytes provide a model which can be used to assess the energy requirements of red cell homeostatic functions. In large part, these functions are localized at or in the red cell membrane. These studies further suggest that, in the intact cell, there is compartmentalization of function with specific sources of energy for some functions. For example, active $\mathrm{Na}^{+}$and $\mathrm{K}^{+}$transport are not necessarily linked. They are differentially affected by glucose depletion, perhaps due to the unique requirement of the $\mathrm{Na}^{+}$pump for ATP derived from PGK.

\section{ACKNOWLEDGMENTS}

The authors gratefully acknowledge the thoughtful criticisms and suggestions of Dr. James H. Jandl and his associates, Thorndike Memorial Laboratory, Boston, Mass., which helped guide our study of the relationship of glycolysis to cation transport. The excellent technical assistance of Miss Domenica Paci, Mrs. Dale Holman, and the statistical guidance of Dr. Robert Reed, Harvard School of Public Health, are greatly appreciated.

This research was supported by U. S. Public Health Service grants 1-T01-AM-05581 and $\mathrm{HD}-02777$ and by a grant from the John A. Hartford Foundation.

\section{REFERENCES}

1. Warburg, O., and W. Christian. 1941. Isolierung and Kristillisation des Gärungferments Enolase. Biochem. Z. $310: 384$.

2. Keitt, A. S. 1967. Asynchronous glycolysis induced by fluoride. Clin. Res. 15: 282. (Abstr.)

3. Feig, S. A., S. B. Shohet, and D. G. Nathan. 1971. Energy metabolism in human erythrocytes. I. Effects of sodium fluoride. J. Clin. Invest. 50: 1731.

4. Whittam, R. 1958. Potassium movements and ATP in human red cells. J. Physiol. (London). 140: 479.

5. Cartwright, G. E. 1968. Diagnostic Laboratory Hematology. Grune \& Stratton, Inc., New York. 4th edition.

6. Adam, H. 1963. Adenosine-5'-triphosphate. Determination with phosphoglycerate kinase. In Methods of Enzymatic Analysis. H. U. Bergmeyer, editor. Academic Press, Inc., New York. 539.

7. Zarkowsky, H. S., and D. G. Nathan. 1970. Influence of erythrocyte membrane adenosine triphosphatase on the metabolism of hemolyzates. J. Lab. Clin. Med. 76: 231.
8. Hohorst, H. J. 1963. L-(+)-lactate. Determination with lactic dehydrogenase and DPN. In Methods of Enzymatic Analysis. H. U. Bergmeyer, editor. Academic Press, Inc., New York. 266.

9. Slein, M. W. 1963. D-glucose. Determination with hexokinase and glucose-6-phosphate dehydrogenase. In Methods of Enzymatic Analysis. H. U. Bergmeyer, editor. Academic Press, Inc., New York. 117.

10. Schröter, W., and H. Heyden. 1965. Kinetik des 2,3diphosphoglyceratumsatzer in menschlichen erythrocyten. Biochem. Z. 341 : 387.

11. Segel, G. B., S. A. Feig, R. L. Baehner, and D. G. Nathan. 1971. Fluorometric analysis of glycolytic intermediates and pyridine nucleotides in peripheral blood cells. J. Lab. Clin. Med. 78: 969.

12. Gloster, J. A., and P. Harris. 1962. Observations on an enzymic method for the estimation of pyruvate in blood. Clin. Chim. Acta. 7: 206.

13. Tosteson, D. C., E. Carlson, and E. T. Dunham. 1956. The effects of sickling on ion transport. I. The effect of sickling on potassium transport. J. Gen. Physiol. 39: 31 .

14. Tosteson, D. C. 1956. The effect of sickling on ion transport. II. The effect of sickling on sodium and cesium transport. J. Gen. Physiol. 39: 55.

15. Goldstein, A. 1964. Correlation. Biostatistics-An Introductory Text. The MacMillan Company, New York. 129.

16. Omachi, A., C. B. Scott, and T. E. Parry. 1969. Influence of glycolysis on NADH content in human erythrocytes. Amer. J. Physiol. 216: 527.

17. Bowler, K., and C. J. Duncan. 1970. The effect of copper on membrane enzymes. Biochim. Biophys. Acta. 196: 116 .

18. Oliveira, M. M., and M. Vaughan. 1964. Incorporation of fatty acids into phospholipids of erythrocyte membranes. J. Lipid Res. 5 : 156.

19. Maizels, M. 1968. Effect of sodium content on sodium efflux from human red cells suspended in sodium free media containing potassium, rubidum, caesium or lithium chloride. J. Physiol. (London). 195: 657.

20. Temkine, H. 1966. Les enzymes du globule rouge hemain. Séparation et caractéristiques. Bull. Soc. Chim. Biol. 48: 771 .

21. Carminatti, H., L. J. De Asuá, E. Recondo, S. Passeron, and E. Rosengurt. 1968. Some kinetic properties of liver pyruvate kinase (type L). J. Biol. Chem. 243: 3051.

22. Shohet, S. B., D. G. Nathan, and M. L. Karnovsky. 1968. Stages in the incorporation of fatty acids into red blood cells. J. Clin. Invest. 47: 1096.

23. Whittam, R. 1964. Transport and Diffusion in Red Blood Cells. The Williams \& Wilkins Co., Baltimore. 150.

24. Schatzmann, H. J. 1953. Herzglykoside als hemstoffe für den aktiven kalium-und natriumtransport durch die erythrocytenmembran. Helv. Phys. Acta. 11: 346.

25. Murphy, J. R. 1963. Erythrocyte metabolism. V. Active cation transport and glycolysis. J. Lab. Clin. Med. 61: 567.

26. Post, R. L., and P. C. Jolly. 1957. The linkage of sodium, potassium and ammonium active transport across the human erythrocyte membrane. Biochim. Biophys. Acta. $25: 118$.

27. Streeten, D. H. P., and A. K. Solomon. 1954. The effect of ACTH and adrenal steroids on $\mathrm{K}$ transport in human erythrocytes. J. Gen. Physiol. $37: 643$. 
28. Tosteson, D. C. 1955. Sodium and potassium transport in red blood cells. In Electrolytes in Biological Systems. A. M. Shanes, editor. The American Physiology Society, Washington, D. C. 123.

29. Solomon, A. K. 1952. The permeability of the human erythrocyte to sodium and potassium. J. Gen. Physiol. $36: 57$.

30. Glynn, I. M. 1956. Sodium and potassium movements in human red cells. J. Physiol. (London). 134: 278.

31. Cividalli, G., H. Locker, and A. Russell. 1971. Increased permeability of erythrocyte membrane in thalassemia. Blood. 37 : 716.

32. Parker, J. C., and J. F. Hoffman. 1967. The role of membrane phosphoglycerate kinase in the control of glycolytic rate by active transport in human red blood cells. J. Gen. Physiol. 50: 893.
33. Schrier, S. L. 1966. Organization of enzymes in human erythrocyte membrane. Amer. J. Physiol. 210: 139.

34. Hoffman, J. F. 1962. Cation transport and structure of red-cell plasma membrane. Circulation. 26: 1201.

35. Post, R. L., C. R. Merritt, C. R. Kinsolving, and C. D. Albright. 1960. Membrane adenosine triphosphatase as a participant in the active transport of sodium and potassium in the human erythrocyte. J. Biol. Chem. 235: 1796.

36. Eckel, R. E., S. C. Rizzo, H. Lodish, and A. B. Berggren. 1966. Potassium transport and control of glycolysis in human erythrocytes. Amer. J. Physiol. 210: 737.

37. Valentine, W. N., H. S. Hsieh, D. E. Paglia, H. M. Anderson, M. A. Baughan, E. R., Jaffé, and O. M. Carson. 1969. Hereditary hemolytic anemia associated with phosphoglycerate kinase deficiency in erythrocytes and leukocytes. N. Engl. J. Med. 280: 529. 